disorder may therefore play a part in the pathogenesis of both IgA nephropathy and Buerger's disease. ${ }^{3}$ The lymphocytes of our first patient carried HLA B5 antigen, which has been associated with both Buerger's disease $^{4}$ and, in some cases, familial IgA nephritis. ${ }^{5}$ The association of the two diseases in our patients may not have been coincidental.

1 Adar R. Buerger's disease. The need for diagnosis criteria. Surgery 1974;76:848.

2 Adar R, Papa MZ, Halpern Z, et al. Cellular sensitivity to collagen in thromboangiitis obliterans. N Engl f Med 1984;308:1113.

3 Emancipator SN, Gallo GR, Lamm ME. IgA nephropathy: perspectives on pathogenesis and classification. Clin Nephrol 1985;24:161-79.

4 McLoughlin G, Helsby C, Evans C, Chapman D. Association of HLA-A9 and HLA-B5 with Buerger's disease. Br Med f 1976;ii:1165-6.

5 Julian BA, Quiggins PA, Thompson JS, Woodford S, Gleason K, Wyatt RJ. Familial IgA nephropathy: evidence of inherited mechanism of disease. N Englf Med 1985;312:202-4.

(Accepted 3 September 1987)

Hôpital Broussais, 75674 Paris Cédex 14, France

P REMY, MD, assistant, department of nephrology

C JACQUOT, MD, assistant, department of nephrology

D NOCHY, MD, assistant, department of pathology

J N FIESSINGER, MD, professor and deputy head, department of internal medicine

M DIALLO, MD, resident, department of nephrology

J BARIETY, MD, professor and head, department of nephrology

Hôpital St-Joseph, 75014 Paris, France

J F MATHIEU, MD, assistant, department of vascular surgery

Correspondence to: Dr Remy

\section{Subacute sclerosing panencephalitis: detection of measles virus sequences in RNA extracted from circulating lymphocytes}

We have shown by an in situ hybridisation technique that measles virus ribonucleic acid (RNA) was present in the peripheral blood lymphocytes of a patient with subacute sclerosing panencephalitis, ${ }^{1}$ as well as in the lymphoid tissue of the appendix of a patient before she developed the disease. ${ }^{2} \mathrm{~A}$ few infected cells were also found in normal seropositive subjects. The large number of persistently infected mononuclear cells in the blood of patients with encephalitis prompted us to look for the presence of viral RNA with a dot blot hybridisation technique.

\section{Patients, methods, and results}

Four patients and four healthy subjects seropositive for measles virus were studied. Mononuclear cells from 5-10 ml of peripheral blood were separated on a Ficoll-Hypaque gradient ${ }^{1}$ and stored at $-80^{\circ} \mathrm{C}$ until required. Vero cells were infected with the Edmonston strain of measles virus for three days. Total RNA was extracted by the lithium chloride urea and phenol procedures ${ }^{3}$ and hybridised at $42^{\circ} \mathrm{C}$ in a solution containing a deoxyribonucleic acid (DNA) labelled with ${ }^{32} \mathrm{P}$ that was specific for measles virus nucleocapsid protein $^{1}$ (specific activity $5 \times 10^{\circ} \mathrm{Bq} / \mu \mathrm{g}$ ) in $50 \%$ formamide; $5 \times$ standard saline citrate (SSC) (1 $1 \times$ standard saline citrate contains $0.15 \mathrm{~mol} / \mathrm{l}$ sodium chloride and $0.015 \mathrm{~mol} / \mathrm{l}$ sodium citrate); $0.1 \%$ sodium dodecyl sulphate (SDS); and $10 \%$ dextran sulphate. After hybridisation the nitrocellulose filter blots were washed four times for five minutes each in $2 \times S S C$ and $0.1 \%$ SDS at room temperature; twice for five minutes each in $2 \times \mathrm{SSC}$ and $0.1 \%$ SDS at $42^{\circ} \mathrm{C}$, once for eight minutes each in $0.1 \times S S C$ and $0.1 \%$ SDS at $42^{\circ} \mathrm{C}$; three times for five minutes each in $0.1 \times S S C$ and $0.1 \% \mathrm{SDS}$ at $50^{\circ} \mathrm{C}$, and dried. Autoradiography was then carried out.

The figure shows $5 \mu \mathrm{g}$ of total RNA then successive twofold dilutions spotted on to the filters. Only background was seen in non-infected Vero cells and in those from seropositive control subjects, whereas measles virus RNA sequences could be seen in the RNA that had been extracted from infected Vero cells and in three of the four preparations of lymphocytes from patients with encephalitis.

In cases 1 and 2 parallel in situ hybridisations indicated detection of viral RNA in over $50 \%$ of the positive cells in case 2 ; less than $0 \cdot 1 \%$ were detected in two out of four of the control subjects.

\section{Comment}

The dot hybridisation assays that we undertook showed that RNA containing measles virus sequences could be extracted from the circulating lymphocytes of patients with subacute sclerosing panencephalitis. The

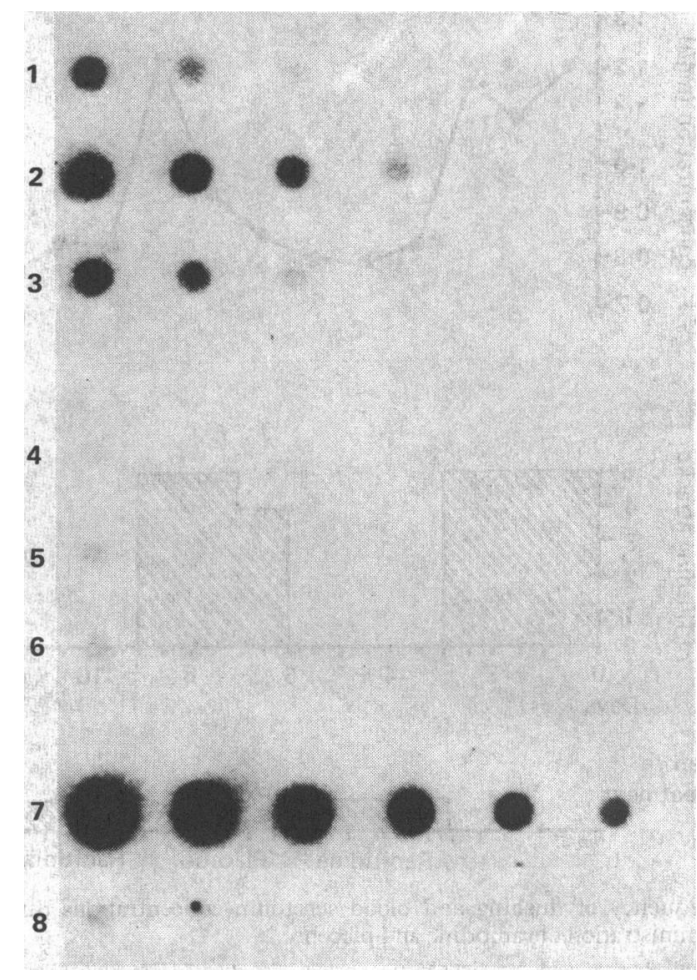

Autoradiograph of dot hybridisation for measles virus RNA in mononuclear cells. Rows 1-3: cells from patients with subacute sclerosing panencephalitis; rows 4-6: cells from seropositive control subjects; row 7: Vero cells infected with measles virus; row 8: non-infected Vero cells.

different autoradiographic signals that we saw among samples from the seropositive patients suggested that a variable amount of viral RNA was conserved in lymphocytes. Loss of the RNA during cell storage and sample handling, however, could also explain the variability in the intensity of the signal. This is suggested by the fact that in a subsequent RNA dot hybridisation analysis performed for case 2 we failed to detect any signal specific for the virus.

These findings indicate that in subacute sclerosing panencephalitis the presence of measles virus RNA in lymphocytes can be analysed by a biochemical method that confirms our previous studies of in situ hybridisation. Such a method has also permitted the detection of measles virus RNA in blood mononuclear cells during the acute and convalescent phases of measles, ${ }^{4}$ and in autoimmune disease associated with high antibody titres to measles virus. ${ }^{5}$ These data confirm our observations that viral genetic information persists in the immune system long after an attack of measles is over.' 'We are currently carrying out experiments to find out which species of molecule contain measles virus sequences.

1 Fournier JG, Tardieu M, Lebon P, et al. Detection of measles virus RNA in lymphocytes from peripheral blood and brain perivascular infiltrates of patients with subacute sclerosing panencephalitis. N Engl f Med 1985;313:910-5.

2 Fournier JG, Lebon P, Bouteille M, Goutieres F, Rozenblatt S. Subacute sclerosing panencephalitis: detection of measles virus RNA in appendix lymphoid tissue before clinical signs. BrMed F 1986;293:523-4.

3 Auffray C, Rougeon F. Purification of mouse immunoglobulin heavy chain messenger RNAs from total myelome tumor RNA. Eur f Biochem 1980;107:303-14.

4 Hyypiä T, Korkiamäki P, Vainionpää R. Replication of measles virus in human lymphocytes. f Exp Med 1985;161:1261-71.

5 Robertson DAF, Zhang SL, Guy EC, Wright R. Persistent measles virus genome in autoimmune chronic active hepatitis. Lancet 1987;ii:9-11.

(Accepted 3 November 1987)

Unité de Recherche sur les Infections Virales (U43 INSERM), Hôpital St Vincent de Paul, 75674 Paris Cedex 14, France

JEAN-GUY FOURNIER, PHD, senior research fellow

JACQUELINE GERFAUX, PHD, senior research fellow

ANNE-MARIE JORET, BSC, research technician

PIERRE LEBON, MD, head, U43 INSERM

Department of Virology, Weizmann Institute of Science, Rehovot, Israel SHMUEL ROZENBLATT, PHD, group head

Correspondence and requests for reprints to: Dr Fournier. 